\title{
Isolepis levynsiana, a New Name for Cyperus tenellus (Cyperaceae)
}

\author{
A. Muthama Muasya \\ Botany Department, University of Cape Town, Rondebosch 7701, South Africa. \\ muthama.muasya@uct.ac.za \\ David A. Simpson \\ Royal Botanic Gardens, Kew, Richmond, Surrey, TW9 3AB, United Kingdom. \\ d.simpson@rbgkew.org.uk \\ Erik Smets \\ National Herbarium of the Netherlands, P.O. Box 9514, NL-2300 RA Leiden, Netherlands; and \\ Laboratory of Plant Systematics, K.U. Leuven, Kasteelpark Arenberg 31, BE-3001 Leuven, \\ Belgium.smets@nhn.leidenuniv.nl
}

Aвstract. The recently published name Isolepis tenella (L. f) Muasya \& D. A. Simpson is illegitimate, because there exists an earlier homonym. A new name, I. levynsiana Muasya \& D. A. Simpson, is proposed for Cyperus tenellus.

Key words: Cyperaceae, Cyperus, Isolepis.

We recently proposed a new combination (Muasya et al., 2006), Isolepis tenella (L. f) Muasya \& D. A. Simpson for the annual Cyperus tenellus L. f. However, an earlier homonym I. tenella (Link) Kunth (Kunth, 1837) exists, referring to the Brazilian Fimbristylis tenella (Link) Schultes, and therefore the later homonym is illegitimate. A new name, I. levynsiana Muasya \& D. A. Simpson, is proposed. The name honors Dr. Margaret Levyns (1890-1975), who was based at the University of Cape Town and whose research forms a vital foundation on the Cyperaceae in the Cape Floristic Region.
Isolepis levynsiana Muasya \& D. A. Simpson, nom. nov. Replaced name: Cyperus tenellus L. f., Suppl. Pl.: 103. 1782. Isolepis tenella (L. f.) Muasya \& D. A. Simpson, Novon 16: 89. 2006, nom. illegit., non Isolepis tenella (Link) Kunth, 1837. TYPE: South Africa, Linnean Herbarium no. 71/2 (lectotype, designated by Muasya et al., 2006: 89, LINN).

Acknowledgment. We thank Gerrit Davidse for pointing out the earlier homonym.

Literature Cited

Kunth, C. S. 1837. P. 213 in Enumeratio Plantarum, Vol. 2. Cotta, Stuttgart.

Muasya, A. M., D. A. Simpson \& E. Smets. 2006. Isolepis tenella, a new combination in Cyperaceae. Novon 16: 89-90. 